\title{
INCLUSION CHEMISTRY, CARBON ISOTOPES AND NITROGEN DISTRIBUTION IN BULTFONTEIN DIAMONDS.
}

\author{
Wilding $^{(1)}$, M.C.; Harte $^{(1)}$, B. and Harris ${ }^{(2)}, J . W$.
}

(1) Dept. of Geology and Geophysics, University of Edinburgh. Edinburgh EH9 3JW, Scotland, U.K, (2) Dept. of Geology and Applied Geology, University of Glasgow, G12 8QQ, Scotland, U.K.

Inclusion-bearing diamonds from the Bultfontein Kimberlite, Kimberley, South Africa have been examined for their inclusion chemistry, nitrogen characteristics and carbon isotope composition (Wilding, 1990). The results have been compared with existing data from other Southern African kimberlites.

Nearly all of the inclusions from the Bultfontein diamonds are of peridotite paragenesis and have an inclusion chemistry similar to other peridotite diamonds. The Bultfontein diamonds have a high abundance of chromite inclusions, a feature shared with other mines in the De Beers Pool (De Beers, Dutoitspan and Wesselton). There is a change in the chemistry of chromite inclusions across the Bultfontein diamonds, chromites located at the centre of the diamond are more magnesian and chrome-rich than the peripheral chromites which are relatively iron-rich. Pressure and temperature estimates for the Bultfontein diamonds suggest a range of pressures of origin of 41 to $55 \mathrm{kbar}$ and temperatures of formation of 930 to $955^{\circ} \mathrm{C}$.

Infrared studies of the Bultfontein diamonds show a range of nitrogen contents from 0 to $1457 \mathrm{ppm}$. Most of this nitrogen occurs as a combination of the Type IaA (two adjacent nitrogens) and Type IaB (four nitrogens) aggregates, with Type IaA dominant.

The carbon isotope composition of the Bultfontein diamonds have a mean $\delta{ }^{13} \mathrm{C}$ value of $-4.66 \%$, a value which is slightly heavier than the mean values for Premier $(-4.84 \% \%$ ), Roberts Victor $(-6.40 \% \%)$ and Finsch $(-5.980 \%$ ). The $\delta$ ${ }^{13} \mathrm{C}$ value for the chromite-bearing diamonds is $-3.760 \%$, and the high abundance of chromites at this mine might account for the slight differences in $\delta 13 \mathrm{C}$ distribution. Ion microprobe studies of a single diamond show a variation of $\delta{ }^{13} \mathrm{C}$ across the diamond of $5.1 \%$ and this variation was found to be related to growth zones identified by cathodoluminescence (Wilding and Harte, 1990). The $\delta{ }^{13} \mathrm{C}$ variation in the single diamond suggests that diamond formation occurred in an open system with a variation in redox conditions controlling both growth and $\delta{ }^{13} \mathrm{C}$

\section{References.}

Wilding, M. C. (1990), "A study of diamonds with syngenetic inclusions." Unpubl. PhD. Thesis, University of Edinburgh.

Wilding, M.C. and Harte, B. (1990) "Carbon isotope variation in a zoned Bultfontein diamond determined by SIMS." Geological society of Australia abstracts, 27, 